\title{
Chromatic Characteristics OF THE RECYCLED FIBERS
}

\section{BOLANCA MiRKOVIC, I. \& BOLANCA, Z.}

Abstract: In the field of sustainable design an important place occupies life cycle of printed products. One of the possibilities to increase the quality of the environment in this area arises from the selection of paper in the fiber type context, expenditures of water and energy and ink in relation to the share of renewable raw materials. In this paper the research results of chromatic characteristics of the fibers obtained by recycling prints made on different types of paper and with conventional and environmentally more favorable inks are presented. Influence of the composition of graphic materials and the dynamics of aging prints, which are processed by deinking flotation are discussed. The research results are scientific contribution in the field of deinking mechanism of aged prints and influence of graphic materials on the chromatic characteristics of the recycled fibers. Results are applicable in the field of sustainable product design and formulation of new materials.

Key words: offset prints, ageing, recycling, chromatic characteristics
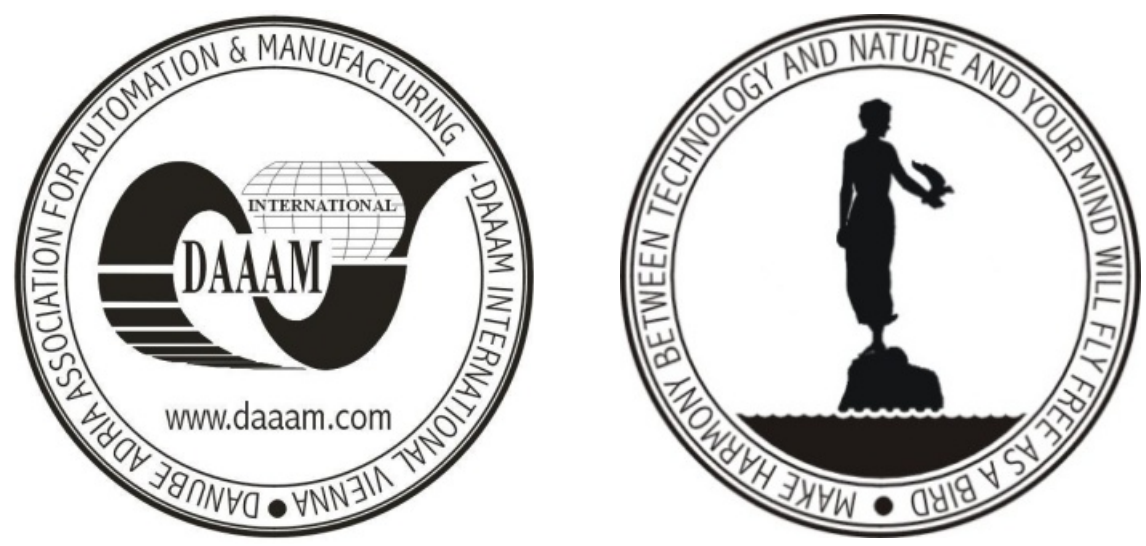

Authors' data: Assistant Prof. PhD. Bolanca Mirkovic, I[vana]; Prof. PhD. Bolanca, Z[denka], University of Zagreb, Faculty of Graphic Arts, Getaldiceva 2, 10000,Zagreb,Croatia, ibolanca@grf.hr, zbolanca@grf.hr

This Publication has to be referred as: Bolanca Mirkovic, I[vana] \& Bolanca, Z[denka] (2009). Chromatic Characteristics of the Recycled Fiber, Chapter 67 in DAAAM International Scientific Book 2009, pp. 693-702, B. Katalinic (Ed.), Published by DAAAM International, ISBN 978-3-901509-69-8, ISSN 1726-9687, Vienna, Austria

DOI: $10.2507 /$ daaam.scibook.2009.67 